UDC 621.785.7: 621.873

DOI 10.36910/6775-2313-5352-2020-16-17

B.P. Sereda ${ }^{1}$, Doctor of Tech. Sci., Prof., seredabp@ukr.net

V.I. Voloh, postgraduate

Dniprovsky State Technical University, Kamianske

\title{
FORMATION OF STRUCTURE OF HOOKS OF LOADING LIFTS IN CONDITIONS OF SHS
}

The article deals with the formation of the structure of hoists for lifting cranes in order to prevent the development of cracks by forming the structure of steel 20 by treatment in the conditions of self-propagating high-temperature synthesis (SHS) to obtain fine-grained ferrite-perlite structure. The conducted researches allow to form a rational structure of steel to exclude the development of cracks in dangerous sections of lifting hooks of hoisting and transport mechanisms working in the shops of metallurgical production. The method of structure control after SHS is developed taking into account the influence of different diameters of hooks.

Keywords: structure, correction factor, self-propagating high-temperature synthesis, crack, fatigue fracture, coercive force, microstructure, experimental sample.

\section{Problem statement}

In the shops of the metallurgical industry the lifting hooks of the suspension of the crane beam $3 \mathrm{t}$ are destroyed. On an external inspection of the destroyed hook it was found that its destruction occurred in cross section along the tangle at the point of transition to the threaded part of the hook, shown in Figure 1.

Analyzing the results of the snapshot of Fig. 1 of the zone of destruction obtained during metallographic research, it can be argued: the zone of fracture, characterized by the presence of a zone of fatigue and fragile destruction (zone of fracture) [1-2].

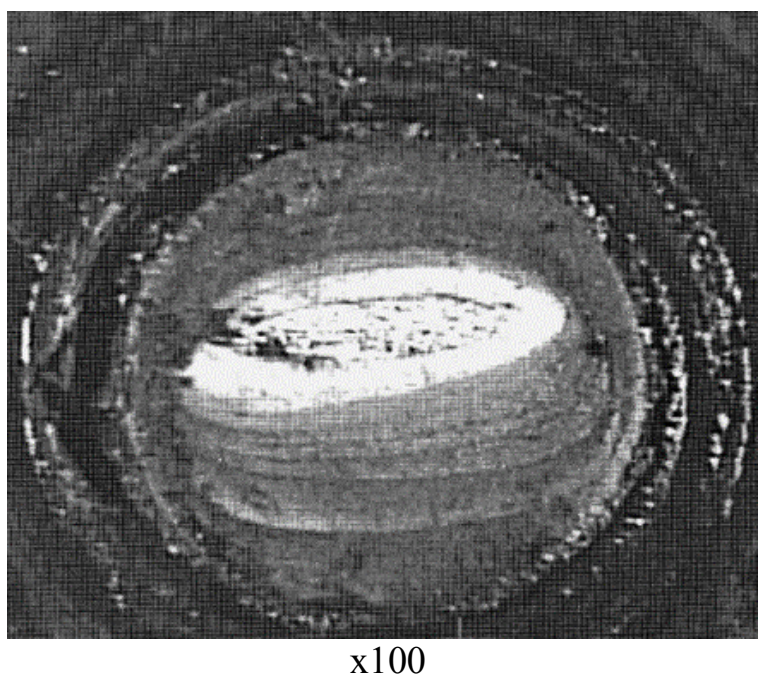

Fig. 1 - breakage of the hook along the tensile transition with fatigue cracks: a - microstructure of the breakage of the hook

Fatigue fracture extends throughout the perimeter, preferably from two opposite sides of the workpiece surface, with a maximum propagation depth of up to $18 \mathrm{~mm}$. The zone of fatigue fracture is characterized by the presence of 8 (eight) lines of zones of fatigue with different distances between them, which divide the fatigue fracture into several sections (the fronts of the fatigue crack propagation in time in several stages. The area of the home area is approximately $5 \%$.

Analysis of the destruction of the threaded part of the hook.

Gradually, the growing fatigue crack after 50-60\% of life reaches a size that becomes visible to the naked eye. When the length and depth of the crack from 0.5 to $1 \mathrm{~mm}$, it can no longer be considered as a micro crack, but as a crack in the engineering sense. After the zones of fatigue cracks occupy a sufficiently large part of the cross section of the hook, then in the rest of the final cross- 
section, there are stresses that exceed the static strength of the material. This leads to a complete breakdown of the hook. Thus, two zones are distinguished on the surface of fractures formed during cyclic loading: the zone of gradual propagation of cracks with a relatively flat surface and the zone of fracture during the last cycles of loading.

After the crack is generated, each subsequent load cycle leads to its gradual growth. With cyclic loading on the hook "stretching - compression" the crack developed at right angles to the direction of the applied voltage. With little cyclic fatigue, the destruction of the hook occurred in the elastoplastic region within $5 \cdot 104$ cycles. The fatigue lines resulting from the temporary stoppage of a crack upon termination of loading are a significant difference in the feature of fatigue fractures. The ratio of the size of the zone of gradual growth of cracks and zone of fracture is a measure of the magnitude of the cyclic stresses that led to the destruction. The cause of the failure of the crane - hook suspension hook is related to the development of fatigue cracks during operation.

In order to improve the structure of steel, steel was treated in SHS [3,4]. To establish the dependence on the influence of the number of special boundaries on the ferrite-pearlite structure of steel 20 and the relationship with the magnitude of the coercive force Ns, the heating of samples No. $1,2,3$ according to the following scheme.

Sample №1- witness, sample №2 SHS treatment, heating at $850^{\circ} \mathrm{C}$ for 60 minutes, sample №2 SHS treatment, 180 minutes and air cooling.

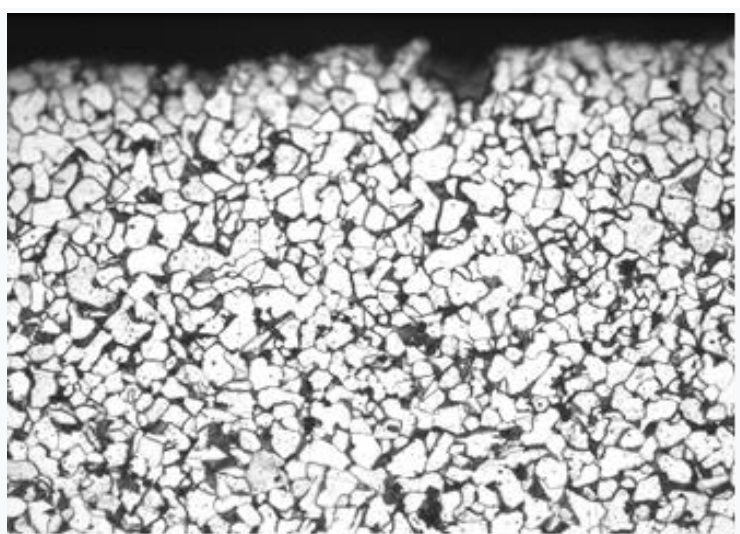

a) $\mathrm{x} 200$

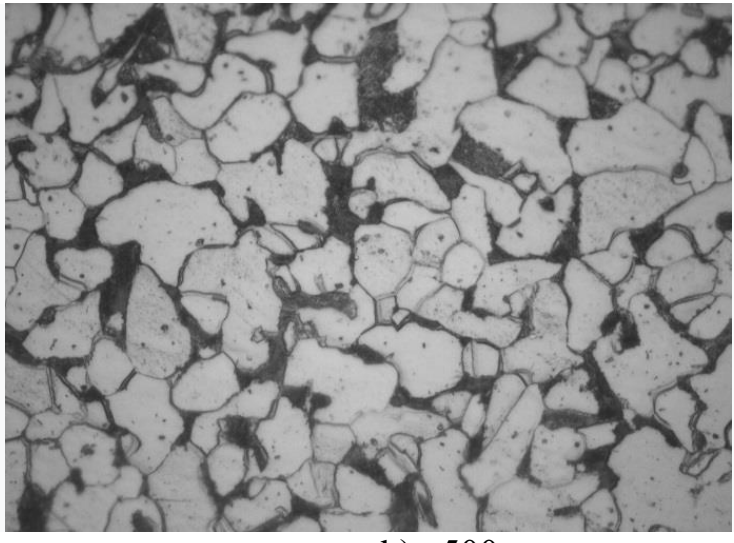

b) $\mathrm{x} 500$

Fig.2 Metallographic structure of the sample-witness №1 of perlite-ferrite in the ratio of 20/80. The magnitude of the coercive force is $\mathrm{Hc}=6,79 \mathrm{~A} / \mathrm{cm}$. The average relative value of the number of special boundaries is $12,66 \%$

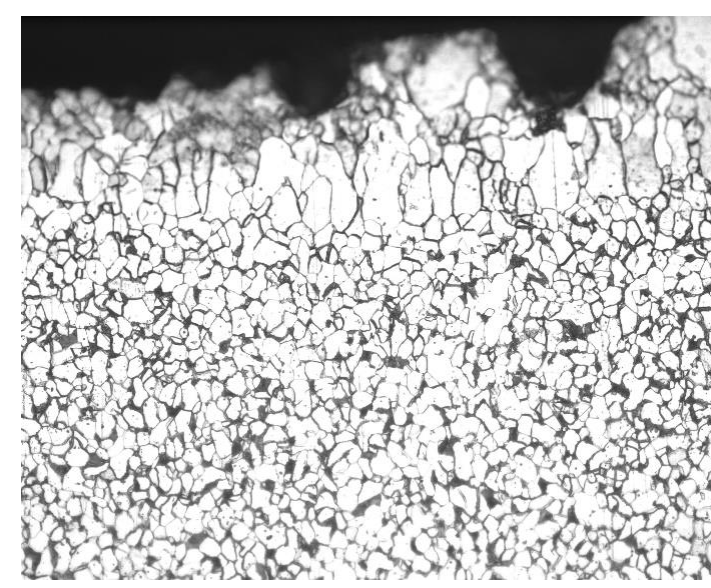

a) $\mathrm{x} 200$

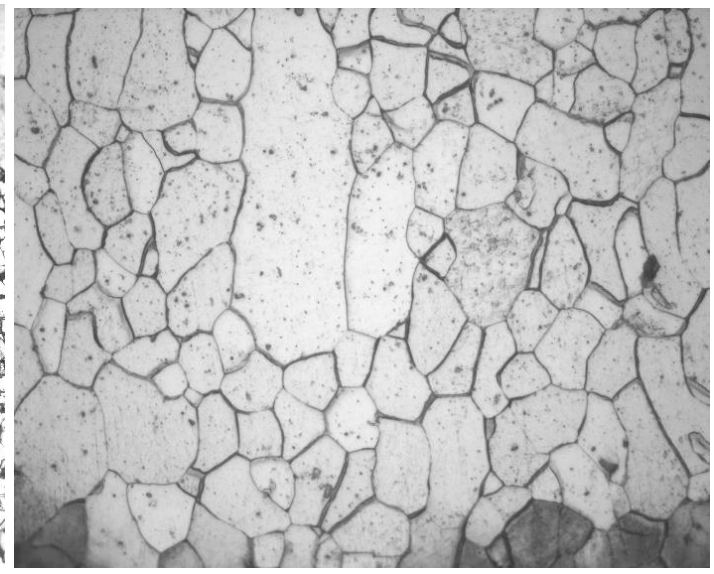

b) $\mathrm{x} 500$

Fig. 3 Microstructure of hook after SHS processing (holding time $60 \mathrm{~min}$ ) and cooling in air

The magnitude of the coercive force is $\mathrm{Hc}=7,58 \mathrm{~A} / \mathrm{cm}$, and the depth of the decarburized layer is from 78,05 до $89,2 \mu \mathrm{m}$. The amount of perlite decreased to $5 \%$. The average relative value of the number of special borders is $19.66 \%$ 


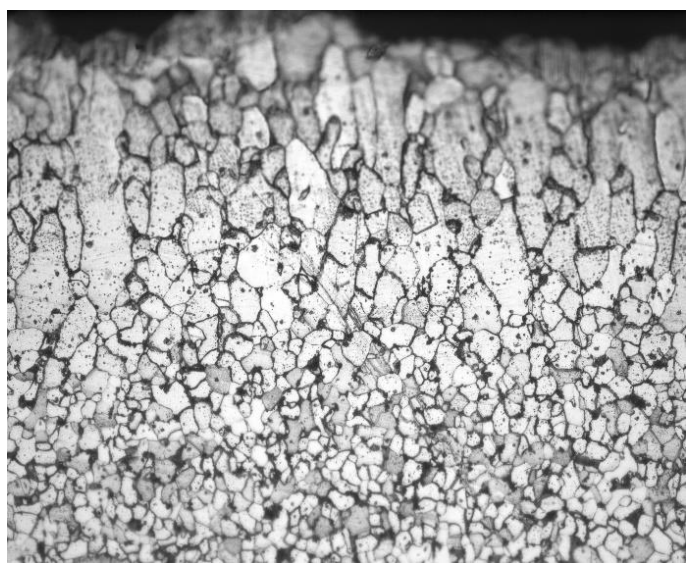

a) $\mathrm{x} 200$

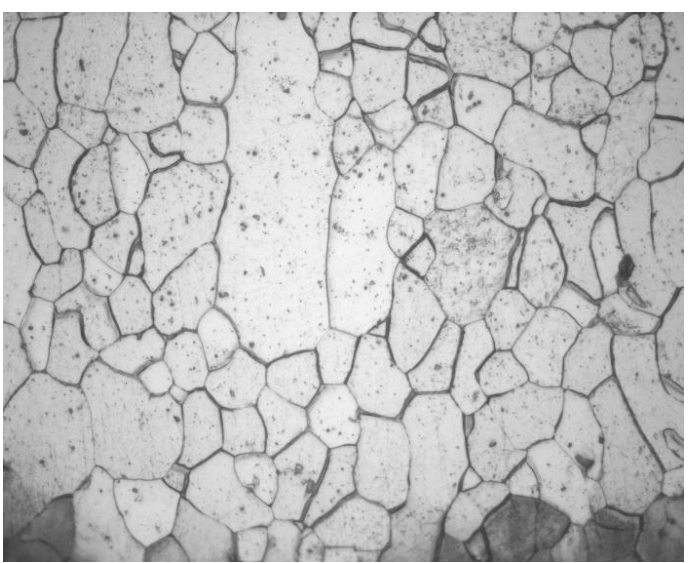

b) $x 500$

Fig.4 Microstructure of hook after SHS treatment (holding time $180 \mathrm{~min}$ ) and cooling in air

The magnitude of the coercive force is $\mathrm{Hc}=7,4 \mathrm{~A} / \mathrm{cm}$ and the depth of the carbonless layer is from 223 to $245 \mu \mathrm{m}$. Analyzing the depth of the carbon-free layer on the sample, it can be established that the layer at a normalization of 3 hours (sample №3) increased by $2,5 \div 2,8$ times as compared to sample №2. The preliminary analysis of the decrease in the coercive value can be explained by the decrease in the amount of perlite in the middle part of the sample, as well as the increased content of special low energy boundaries. The average relative value of the number of special borders is $34,45 \%$.

The structure of the sample in such processing in the SHS environment is fine - grained and meets the requirements [5]. Studying the properties of steel shows promising management by creating special low energy boundaries in the structure. Increasing the relative number of special boundaries leads to a decrease in the grain energy of the boundary complex, which affects the magnetic properties of steel.

The increased content of special boundaries in the carbon-free layer compared to the parent metal can be explained by the absence of perlite or other low-mobility elements of the structure $[6,7,8]$. Thus, it can be assumed that the emergence and interaction of special boundaries in the SHS process contributes to the mechanism of cyclic growth and grinding of ferrite-perlite steel grain.

The control of the structure of hooks after SHS can be carried out using a magnetic coercimeter method of control. However, the disadvantage of the magnetic method of NC based on the coercive force of HC proposed in [9] is its sensitivity to local changes in the diameter of the threaded part of the shank of the hook, which creates additional difficulties in the interpretation of the control results. Where, when changing the physical properties of a metal section (for example, the loss of elastic properties of metal in an intertwining thread space), a distortion of the magnetic field occurs caused by a change in the magnetic properties of the metal at that site

Therefore, for more accurate determination of the resource of hooks by means of a magnetic method of control, it is recommended in addition [9] to use experimental samples with variable diameter with known chemical and mechanical properties and coercive force Hc [10].

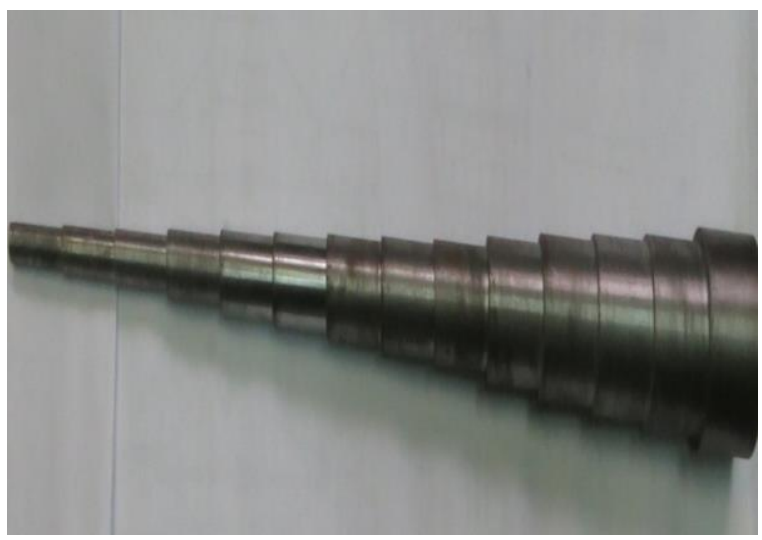

a)

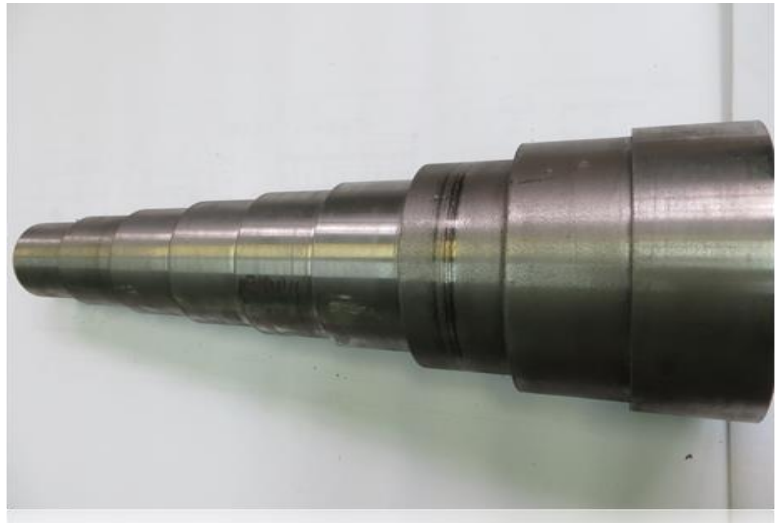

b)

Fig. 5 Experimental specimens of steel 20 for determining the correction factor: a) sample diameter from 12 to $64 \mathrm{~mm}, \mathrm{~b}$ ) sample diameter from 70 to $170 \mathrm{~mm}$ 
Using the correlation equation and calculations in [9], the formula for determining the tensile strength for hooks of load-lifting cranes was obtained.

$$
\mathrm{H}_{\mathrm{c}}{ }^{\text {B }}=0,026 \times \mathrm{XG}_{\mathrm{B}}-3,2
$$

where: $\mathrm{H}_{\mathrm{c}}^{\mathrm{B}}$ - the calculated value of the coercive force to determine the strength of the hook shank in $\mathrm{A}$ $/ \mathrm{cm}$,

$\mathrm{G}_{\mathrm{B}}-$ is the tensile strength in MPa
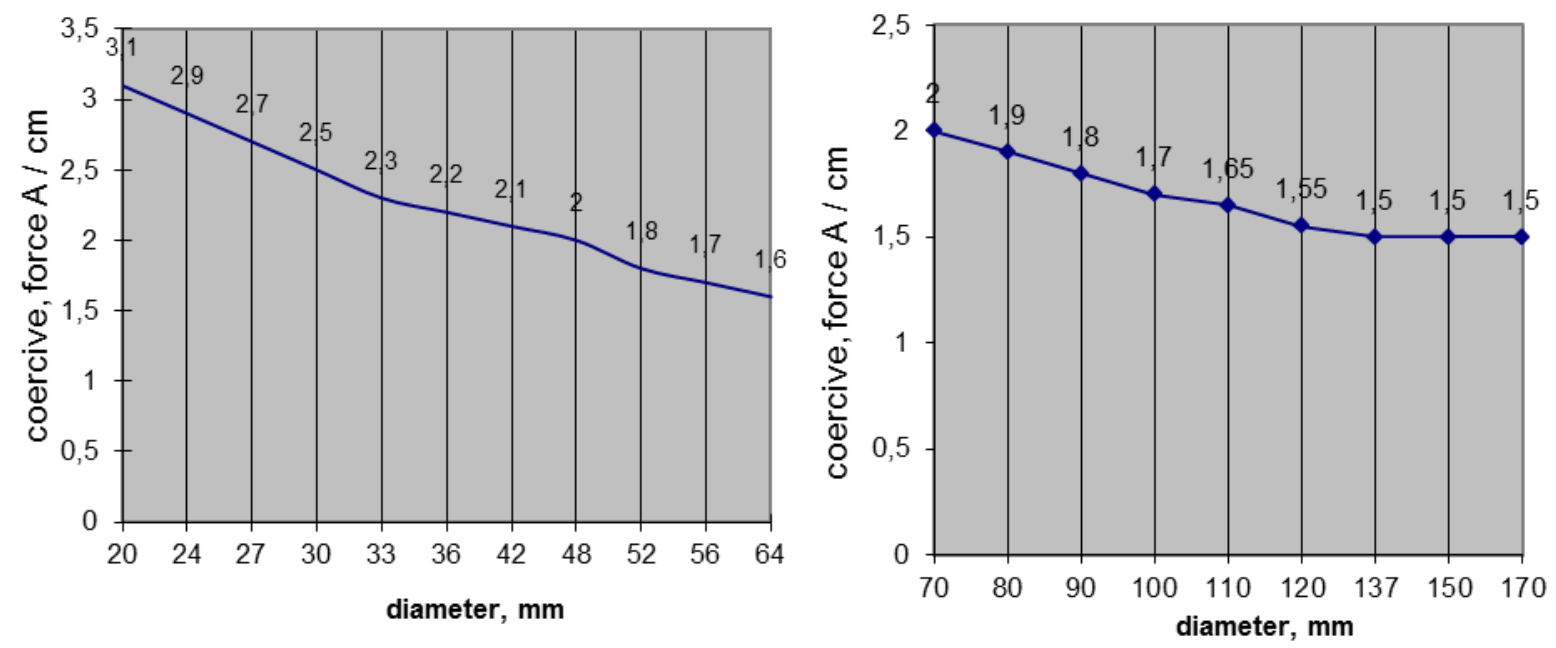

Fig. 6 The graph of the coercive force versus the diameter of the experimental sample with with variable section: a) diameter from 20 to $64 \mathrm{~mm}, \mathrm{~b}$ ) diameter from 70 to $170 \mathrm{~mm}$

However, this formula does not take into account the correction factor determined by the experimental samples. After calculations, formula (1) takes the form

$$
\mathrm{H}_{\mathrm{c}}{ }^{\mathrm{B}}=0,026 \times \mathrm{G}-3,2
$$

where: $\mathrm{H}^{\mu}$ - the correction factor obtained when recalculated on the experimental samples

Using the formula and substituting the obtained correction factor in formula (2) we obtain the calculated value of the tensile strength.

\section{Conclusions:}

In the course of the conducted researches it is established that after treatment in conditions of SHS of steel 20 after 3 hours of isothermal holding at $850^{\circ} \mathrm{C}$ leads to formation of fine-grained structure which increases the physical and mechanical properties of steel in 1,2-1,6 times

A method for controlling the structure of shanks of hoists of hoists of cranes is established and proposed, where it is necessary to take into account the correction factor for each diameter under which control is made, where the error from accounting for the difference of diameters is eliminated

The method of control for the control of shanks of hooks taking into account the difference of diameters MK 230-140-15 is developed. Patent for utility model received in Ukrpatent № 99528 dated 09.12.2015, "Experimental sample for control of mechanical stresses in steel products".

\section{References}

1. Sereda B.P/ New materials in metallurgy: textbook. tool. for students. High schools /; ZDIA. - Zaporizhzhia: 2009. - 394 p.

2. Sereda B.P. Metal science and heat treatment of ferrous and non-ferrous metals: textbook. for students. University of Zaporozhye: ZDIA, 2008.- 302 p.

3. Sereda B.P. Surface hardening of materials working under conditions of complex influence of aggressive substances: monograph / Dnipro. state. tech. Universities (DDTU). - Kamenskoe: DDTU, 2019. - $172 \mathrm{p}$. 
4. Sereda BP, Kruglyak IV, Zherebtsov OA, Belokon Yu.O. Metal processing by pressure at non-stationary temperature conditions. Monograph.-.-Zaporozhye: ZDIA, 2009.- 252 p.

5. GOST 2105-75 Forged stamped hooks. Technical conditions

6. Bolshakov V.I., Sukhomlin V.I., Volokh V.I., Effect of annealing temperature on the formation of special boundaries in armco-iron / Construction, materials science, mechanical engineering // Sat. Scientific Trudov.Vyp. 80, - Dnepropetrovsk-, Higher Educational Institution "PGASA", 2015.- P.67-70.

7. Bolshakov V.I., Sukhomlin V.I., Sobolevsky S.I., Ovcharuk S.A., Volokh V.I., Effect of annealing on the structure and properties of cold-deformed low-carbon steel / Construction, materials science, mechanical engineering // Sat . Scientific Trudy.Vyp. 80, - Dnepr-, State Higher Educational Institution "PGASA", 2017.- P.37-41.

8. Sukhomlin V.I., Volokh V.I., Effect of normalization duration on the structure of magnetic properties and special boundaries in low-carbon steel. Science, Society, Education: Topical Issues and Development Prospects Materials of the First International Scientific and Practical Conference (Kharkiv metro station 16-17, 2019). M. Kharkiv, 2019.S. 271-276.

9. Demichev V.N. Evaluation and improvement of the operation safety of hook suspensions and hoisting cranes: dis. ... cand. tech. sciences / V.N. Demichev. - Novocherkassk, 2011 .- 181 p.

10. Pat. 99528 Ukraine, IPC G01L 1/12. An experimental sample for the control of mechanical stresses in steel parts / [Volokh VI, Sukhomlin VI, Mospan VV, Boyko VM, Motsniy VV ]; applicant and patentee Public Joint Stock Company «Dniprovsky Metallurgical Works named after F.E. Dzerzhinsky ”. - № in 2014 13815; 23/02/2014; Publ. 10.06.2015, Bul.№11.

\section{ФОРМУВАННЯ СТРУКТУРИ ГАКІВ ВАНТАЖОПОДЙОМНИХ КРАНІВ В УМОВАХ СВС}

У статті розглянуто формування структури гаків вантажопідіймальних кранів 3 метою запобігання розвитку трішин иляхом формування конструкиї сталі 20 шляхом обробки в умовах само розповсюджуваного високотемпературного синтезу (СВС) для отримання дрібнозернистої ферито-перлітової структури. Проведені дослідження дозволяють сформувати рачіональну структуру сталі для виключення розвитку тріщин на небезпечних ділянках підйомних гаків підйомно-транспортних механізмів, щуо праџюють в цехах металургійного виробництва. Розроблена методика контролю структури після СВС 3 урахуванням впливу різних діаметрів гаків.

Ключові слова: структура, поправочний коефіиієнт, саморозповсюджуючий високотемпературний синтез, тріщина, втомне руйнування, коериитивна сила, мікроструктура, експериментальний зразок.

\section{Література}

1. Середа Б. П. Нові матеріали в металургії : навч. посіб. для студ. ВНЗ /; ЗДІА. Запоріжжя : 2009. - 394 c.

2. Середа Б. П. Металознавство та термічна обробка чорних та кольорових металів: підруч. для студ. вузів.-Запоріжжя: ЗДІА, 2008.- 302 с.

3.Середа Б. П. Поверхневе зміцнення матеріалів працюючих в умовах комплексного впливу агресивних речовин : монографія / Дніпров. держ. техн. ун-т (ДДТУ). - Кам'янське : ДДТУ, 2019. - 172 с.

4. Середа Б.П., Кругляк І.В., Жеребцов О.А., Бєлоконь Ю.О. Обробка металів тиском при нестаціонарних температурних умовах. Монографія.- .-Запоріжжя: ЗДІА, 2009.- 252 c.

5. ГОСТ 2105-75 Крюки кованые штампованные. Технические условия.

6. Большаков В.И., Сухомлин В.И., Волох В.И., Влияние температуры отжига на формирование специальных границ в армко-железе / Строительство, материаловедение, машиностроение //Сб. научн.трудов.Вып.80,- Днепропетровск-, ГВУЗ «ПГАСА», 2015.- С.6770.

7. Большаков В.И., Сухомлин В.И., Соболевский С.И., Овчарук С.А., Волох В.И., Влияние отжига на структуру и свойства холоднодеформированной низкоуглеродистой стали / Строительство, материаловедение, машиностроение //Сб. научн.трудов.Вып.80,- Днепр-, ГВУЗ «ПГАСА», 2017.- С.37-41.

8. Сухомлин B.I., Волох В.І., Влияние длительности нормализации на структуру магнитные свойства и специальные границы в низкоуглеродистой стали. Science, Society, 
Education: Topical Issues and Development Prospects матеріали тез доповідей I міжнародної науково-практичної конференції (м. Харьків 16-17 грудня 2019р.). м. Харьків, 2019. С.271-276.

9. Демичев В.Н. Оценка и повышение безопасности эксплуатации крюковых подвесок и грузоподъемных кранов: дис. ... канд. техн. наук / В.Н. Демичев. - Новочеркасск, 2011. — 181 c.

10. Пат. 99528 Україна, MПК G01L 1/12. Експериментальний зразок для контролювання механічних напружень у сталевих деталях / [Волох B.I., Сухомлин B.I., Мосьпан В.В., Бойко B.M., Моцний В.В. ]; заявник і патентовласник Публічне Акціонерне Товариство «Дніпровський металургійний комбінат імені Ф.С. Дзержинського». - № u 2014 13815; заявл.23.02.2014; опубл.10.06.2015, Бюл.№11.

\section{ФОРМИРОВАНИЕ СТРУКТУРЫ КРЮКОВ ВАНТАЖОПОДЙОМНИХ КРАНОВ В УСЛОВИЯХ СВС}

В статье рассмотрено формирование структуры крюков грузоподъемных кранов $c$ иелью предотвращения развития трещин путем формирования конструкции стали 20 путем обработки в условиях же распространяемого высокотемпературного синтеза (СВС) для получения мелкозернистой феррито-перлитовой структуры. Проведенные исследования позволяют сформировать раџиональную структуру стали для исключения развития трещин на опасных участках подъемных крюков подъемно-транспортных механизмов, работающих в иехах металлургического производства. Разработана методика контроля структуры после СВС с учетом влияния различных диаметров крюков.

Ключевые слова: структура, поправочный коэффициент, саморозповсюджуючий высокотемпературный синтез, трещина, усталостное разрушение, коэриитивная сила, микроструктура, экспериментальный образец.

\section{ФОРМУВАННЯ СТРУКТУРИ КРЮКОВ ВАНТАЖОПОДЙОМНІХ КРАНІВ В УМОВАХ CBC}

У статті розглянуто формування структури гаків вантажопідіймальних кранів 3 метою запобігання розвитку тріщин шляхом формування конструкції стали 20 шляхом обробки в умовах же розповсюджуваного високотемпературного синтезу (СВС) для отримання дрібнозернистої ферріто-перлітової структури. Проведені дослідження дозволяють сформувати раџіональну структуру стали для виключення розвитку тріщин на небезпечних ділянках підйомних гаків підйомно-транспортних механізмів, щяо праџюють в иехах металургійного виробництва. Розроблено методику контролю структури після $C B C$ з урахуванням впливу різних діаметрів гаків.

Ключові слова: структура, поправочний коефічієнт, саморозповсюджуючій високотемпературний синтез, тріщина, втомне руйнування, коерцитивної сила, мікроструктура, експериментальний зразок. 